\title{
Internalisasi Nilai Peduli Lingkungan di Persekolahan: Studi Kasus Ecopesantren SPMAA Lamongan Jawa Timur
}

\author{
Rihlah Nur Aulia \\ Fakultas Ilmu Sosial, Universitas Negeri Jakarta \\ rihlah-nuraulia@unj.ac.id \\ Sofyan Sauri \\ Universitas Pendidikan Indonesia \\ sofyansauri@upi.edu \\ Faisal M.Jasin \\ Kementerian Negara Lingkungan Hidup dan Kehutanan \\ faisal_mjasin@yahoo.com \\ Sari Narulita \\ Fakultas Ilmu Sosial, Universitas Negeri Jakarta \\ sari-narulita@unj.ac.id \\ Firdaus Wajdi \\ Fakultas Ilmu Sosial, Universitas Negeri Jakarta \\ Firdaus.wajdi@unj.ac.id \\ Dian Elvira \\ Fakultas Ilmu Sosial, Universitas Negeri Jakarta \\ dianelnais8@gmail.com
}

Naskah diterima:15-11-2019, direvisi:24-01-2020; disetujui: 28-01-2020

\begin{abstract}
This study aims to find out how to internalize the value of ecopesantren in shaping the character of caring for the environment. The theory used is the Ecopesantren theory and the value internalization theory. This research is qualitative research by collecting data through field observations, documentation, literature studies, and interviews with the Boarding School Leaders, teachers, and students. This study concludes: first, efforts to internalize the value of ecopesantren in shaping the character of caring for the environment, through; (1), Islamic boarding school policy. (2), the curriculum in schools. (3) extracurricular activities. Second, the process of internalization of ecopesantren values in shaping the character of environmental care in SPMAA Lamongan Islamic boarding school in East Java, through three stages, namely: first, the stage of value transformation. Second, the third Value transaction stage, the transinternalization stage.
\end{abstract}

Keywords: internalization of values, ecopesantren, character care about the environment

\section{Abstrak}

Penelitian ini bertujuan untuk mengetahui bagaimana internalisasi nilai ecopesantren dalam membentuk karakter peduli lingkungan. Teori yang digunakan adalah teori internalisasi nilai. Penelitian ini merupakan penelitian kualitatif dengan pengumpulan data melalui observasi lapangan, dokumentasi, studi literatur dan wawancara dengan Pimpinan Pondok Pesantren, guru, serta para santri. Penelitian ini menyimpulkan: 
pertama,upaya internalisasi nilai ecopesantren dalam membentuk karakter peduli lingkungan, melalui; (1), Kebijakan pondok Pesantren. (2), kurikulum di sekolah. (3), kegiatan ekstrakulikuler.. Kedua, Proses internalisasi nilai ecopesantren dalam membentuk karakter peduli lingkungan di pondok pesantren SPMAA Lamongan Jawa Timur., melalui 3 tahapan, yaitu: pertama, tahap transformasi nilai. Kedua, tahap transaksi milai ketiga, tahap transinternalisasi

Kata Kunci: internalisasi nilai, ecopesantren, karakter peduli lingkungan

\section{Pendahuluan}

Model Pendidikan berbasis karakter menjadi bagian dari tradisi pendidikan di Indonesia (Sauri, 2012). nilai-nilai yang ditanamkan dalam diri warga Indonesia, telah dirumuskan Kementerian Pendidikan Nasional Indonesia khususnya bagi siswa, dalam upaya membangun dan menguatkan karakter bangsa. Adapun 18 nilai-nilai dalam pendidikan karakter tersebut, sebagaimana berikut: nilai religius, nilai jujur, nilai toleransi, nilai disiplin, nilai kerja keras, nilai kreatif, nilai mandiri, nilai demokratis, nilai rasa ingin tahu, nilai semangat kebangsaan, nilai cinta tanah air, nilai menghargai prestasi, nilai bersahabat, nilai cnta damai, nilai gemar membaca, nilai peduli lingkungan, nilai peduli sosial, dan nilai tanggung jawab.

Karakter peduli lingkungan adalah salah satu bagian penting yang ditanamkan bagi siswa di tengah degradasi lingkungan saat ini. Karakter peduli terhadap lingkungan merupakan sikap dan tindakan yang selalu berupaya mencegah kerusakan lingkungan alam sebagai tempat kehidupan, dan melakukan upaya-upaya untuk memperbaiki kerusakan alam yang sudah terjadi terutama kerusakan yang diakibatkan oleh ulah tangan manusia.

Adapun, Nilai karakter yang ditanamkan berupa sikap dan tindakan yang selalu berusaha dalam mencegah kerusakan pada lingkungan alam sekitarnya. Juga mengembangkan upaya untuk memperbaiki kerusakan alam yang sudah terjadi dan selalu memberikan pertolongan pada makhluk yang membutuhkan. Kondisi fenomena seperti ini, karakter peduli lingkungan pada peserta didik dapat terbentuk melalui budaya yang diciptakan secara kondusif, adapun school culture yang kondusif merupakan keseluruhan latar fisik lingkungan, suasana, rasa, sifat dan iklim sekolah yang secara produktif mampu memberikan pengalaman baik bagi tumbuh kembangnya karakter peserta didik seperti yang diharapkan (Sauri, 2017).

Pendidikan lingkungan hidup sejatinya tidak saja mengajarkan teori tentang pelestarian lingkungan. Pendidikan lingkungan hidup juga harus sejalan dengan praktek langsung di lapangan mengenai pelestarian lingkungan serta langsung dilaksanakan setiap harinya sebagai wujud pelaksanaan pendidikan lingkungan hidup. 
HAYULA: Indonesian Journal of Multidisciplinary Islamic Studies, Vol. 4, No. 1, Januari 2020 DOI:https://doi.org/10.21009/hayula.004.1.05

Pondok pesantren menjadi wadah yang cocok untuk memfasilitasi pendidikan lingkungan hidup yang diperlukan masyarakat. Pesantren dan kegiatan setiap jenjang pendidikannya dimulai dari tingkat tsanawiyah hingga mahad aly memiliki perannya masing-masing (Wajdi \& Aulia, 2019). Pendidikan lingkungan hidup yang diajarkan di pondok pesantren hasilnya akan jauh lebih optimal dibandingkan dengan lembaga pendidikan lainnya karena pendidikan lingkungan hidup di pondok pesantren dapat langsung dipraktekkan dalam kehidupan sehari-hari di dalam pesantren yang kemudian akan mendarah daging sebagai kebiasaan hidup santrinya (Abdurrahman, 2006). Dengan kata lain, terdapat nilai pesantren dalam pendidikan karakter bagi santri (Sauri, 2015).

Pesantren mempunyai posisi yang strategis dalam mendidik penerus bangsa umat Islam yang ramah dan peduli terhadap lingkungan sekitar (Aulia, et al., 2018). Dalam hal ini pesantren merupakan lembaga pendidikan Islam swadaya masyrakat yang mandiri dalam perannya juga dapat memberikan kontribusi penting terhadap perawatan lingkungan, baik sekarang atau masa depan nanti, karena lembaga ini merupakan tempat menggembleng kader santri yang diharapkan mampu menjawab tantangan keperluan pengetahuan agama yang didalamnya termasuk pengetahuan mengenai lingkungan.

Potensi yang dimiliki oleh pondok pesantren membuat Kementrian Lingkungan Hidup Republik Indonesia pada tahun 2008 mengusulkan program Ecopesantren yang memberikan penghargaan kepada pesantren yang mempunyai inistiatif dan inovasi dalam berperan serta untuk pelestarian lingkungan (Mangunjaya, 2014). Penelitian yang dilakukan oleh Rihlah Nur Aulia, Dkk, menyimpulkan bahwa ecopesantren berasal dari dua unsur kata yakni eco dan pesantren (Aulia, Setianingsih, \& Narulita, 2019). Eco atau eko - yang diadaptasi ke dalam bahasa Indonesia- dengan konotasi erat berhubungan pada ilmu ekologi, yaitu ilmu yang mempelajarai tentang interaksi makhluk hidup dengan lingkungan alam sekitarnya.

Pondok pesantren merupakan lembaga pendidikan Islam khas Indonesia yang mempunyai elemen pesantren yaitu: pondok, mesjid, pengajaran kitab klasik, santri dan kiyai. Sehingga, ecopesantren adalah model pengelolaan lingkungan yang dilakukan berbasisi pesantren dengan 5 indicator, sebagai pesantren "ramah lingkungan" pesantren tersebut dapat menunjukkan, bagaimana manajemen lingkungan, kontribusi atau partispasinya pada pelestarian atau konservasi lingkungan (Aulia, Jasin, \& Irma, 2019). Ecopesantren memiliki indikator yang harus ditetapkan sebagai berikut. Pertama, yaitu faktor geografis, kedua, kebijakan pesantren peduli dan berbudaya lingkungan. Ketiga, pengembangan kurikulum berbasis lingkungan. Keempat, yaitu pengembangan kegiatan 
lingkungan berbasis partisipatif. Kelima, pengelolaan sarana pendukung pesantren ramah lingkungan (Aulia, Mardhiah, Gunawan, \& Isnaini, 2018).

Internalisasi nilai ecopesantren menjadi role model dalam mengubah perilaku masyarakat pesantren untuk berperan dalam pelestarian lingkungan serta pemeliharaan sumber daya alam maka sangat penting dikaji sejauh mana lembaga ini dapat menjadi contoh dalam melaksanakan perannya di tengah-tengah masyarakat (Munawaroh, Ghozali, \& Fuad, 2019).

Berdasarkan uraian di atas, menganalisis bagaimana proses internalisasi nilai peduli lingkungan dengan mengoptimalkan potensi persekolahan, sebagai lembaga pendidikan formal dalam proses internalisasi nilai peduli lingkungan kepada peserta didik. Berdasarkan latar belakang inilah, perlu dicari contoh sekolah berbasis pendidikan khas Islam Indonesia, yang mewakili karakteristik sebagian besar sekolah model pendidikan khas Indonesia, dan telah dapat menginternalisasikan nilai ecopesantren dalam membentuk karakter peduli lingkungan kepada peserta didiknya. Salah satunya adalah sekolah khas Islam Indonesia, yaitu pondok pesantren.

Pesantren Sumber Pendidikan Agama Allah yang kemudian disingkat menjadi SPMAA, merupakan bagian dari yayasan SPMAA. Yayasan SPMAA sendiri didirikan pada tanggal 27 Oktober 1961. Yayasan ini berdiri di sebuah desa kecil bernama Desa Turi di Kabupaten Lamongan, Provinsi Jawa Timur. Pesantren SPMAA juga merupakan salah satu pesantren yang ditunjuk oleh Kementrian Lingkungan Hidup sebagai eco-pesantren pada tahun 2012. Alasan pemberian label ecopesantren pada pesantren SPMAA adalah pemenuhan semua indikator ecopesantren pada pesantren ini. Dengan demikian, Pondok Pesantren SPMAA Lamongan Jawa Timur merupakan salah satu model ecopesantren yang menanamkan karakter peduli lingkungan. Internalisasi nilai ecopesantren dalam membentuk karakter peduli lingkungan, menjadi menarik untuk dianalisis secara mendalam.

\section{Metode Penelitian}

Penelitian ini adalah penelitian kualitatif. Adapun Penelitian kualitatif berarti data yang dikumpulkan bukan berupa angka-angka tetapi data tersebut berasal dari naskah wawancara, dokumen pribadi, catatan memo, catatan lapangan dan dokumen resmi lainnya (Lexy, 2001). Tujuan penelitian ini adalah menggambarkan realita empirik dibalik fenomena secara mendalam, rinci dan tuntas. Lokasi penelitian yang menjadi tempat penelitian ini dilaksanakan berada di Pondok Pesantren SPMAA Lamongan Jawa Timur. 
HAYULA: Indonesian Journal of Multidisciplinary Islamic Studies, Vol. 4, No. 1, Januari 2020 DOI:https://doi.org/10.21009/hayula.004.1.05

Sumber data dari penelitian ini berasal dari data primer dan data sekunder. Data primer menggunakan data berupa hasil observasi, wawancara dan juga angket (pimpinan, guru, pengurus pondok pesantren, santri, wali santri dan masyarakat sekitar pesantren) untuk mendapatkan informasi langsung mengenai konsep internalisasi nilai peduli lingkungan di persekolahan. Data sekunder yang digunakan berasal dari sumber bacaan dan berbagai macam sumber lainnya yang terdiri dari buku-buku, jurnal sampai dokumen resmi dari berbagai instansi. Selain itu, dapat berupa lampiran-lampiran dari badan-badan resmi sepeti kementerian-kementerian, hasil-hasil studi, tesis, disertasi, studi historis dan sebagainya. Data sekunder digunakan untuk memperkuat temuan dan melengkapi informasi yang telah dikumpulkan melalui wawancara langsung dengan pihak pesantren.

Teknik pengumpulan data yang digunakan berupa observasi langsung, wawancara, dokumentasi dan analisis data. Observasi langsung adalah cara pengambilan data dengan menggunakan mata tanpa ada pertolongan alat standar lain untuk keperluan tersebut (Arikunto, 2006). Observasi ini digunakan untuk penelitian yang telah direncanakan secara sistematik tentang bagaiman konsep pengelolaan lingkungan berbasis pesantren. Selanjutnya adalah awancara menggunakan alat yang dinamakan interview guide (panduan wawancara) yang akan ditanyakan pada tokoh di pondok pesantren tersebut. Kemudian adalah dokumentasi yang berupa catatan-catatan kecil penulis dari hasil observasi, foto-foto dan rekaman kegiatan di pondok pesantren beserta saran dan prasarananya, buku-buku, jurnal dan hasil penelitian

Analisis data yang dilakukan setelah menggunakan teknik pengumpulan data diatas yaitu mengolah dan menganalisis data tersebut dengan menggunakan analisis secara deskriptif-kualitatif.

\section{Hasil dan Pembahasan}

\section{A. Upaya internalisasi Nilai Ecopesantren dalam Membentuk Karakter Peduli Lingkungan}

\section{Internalisasi Nilai Ecopesantren dalam Membentuk Karakter Peduli Lingkungan Melalui Kebijakan Pondok Pesantren}

Kebijakan pesantren yang berwawasan lingkungan dapat dilihat dari visi dan misi, motto pesantren, nilai dasar pesantren serta strategi dasar pesantren. Pesantren SPMAA memiliki visi “Bersama para Pihak Mengembalikan Nilai-nilai, Hak Manusia, Bumi, Alam dan Isinya pada Aslinya”. Visi tersebut dengan jelas menggambarkan adanya porsi besar perhatian yang diberikan oleh pesantren untuk alam atau lingkungan. Dari visi tersebut, 
dapat dilihat pesantren SPMAA berupaya untuk mengembalikan nilai-nilai yang ada di masyarakat saat ini menjadi nilai-nilai ideal yang seharusnya berlaku sesuai kodratnya termasuk nilai-nilai mengenai alam atau lingkungan. Visi tersebut kemudian dituangkan pada misi, motto, nilai dasar dan strategi dasar pesantren yang terus diberikan dan diajarkan kepada santri.

Motto pesantren SPMAA adalah "Berdoa, Belajar, Bekerja. Ingat Allah, Ingat Mati, Kasih Sesama”. Pesantren SPMAA juga memiliki semboyan yang berhungan dengan lingkungan yang di tanamkan kepada para santrimya yaitu "sampah adalah berkah" yang memiliki makna jika sampah hanya di buang begitu saja maka sampah tersebut tidak memiliki nilai dan hanya menjadi sampah. Namun jika sampah yang berserakan dapat diolah maka sampah tersebut menjadi berkah dan menjadi nilai ibadah.

Strategi dasar pesantren SPMAA berangkat dari permasalahan jangka panjang hidup tanpa nilai ketuhanan dan lamanya dari kepemimpinan umat serta orientasi hidup sesaat menjadi rusaknya tatanan nilai, budaya, hukum, akal budi, sosial dan lingkungan. Maka diperlukan strategi baru dan besar untuk mengembalikan pada aslinya secara cepat, tepat, terencana, teroganisir, dan benar. Dengan 5 strategi dasar: memanusiakan manusia, mengagamakan agama, mengislamkan islam, mengimankan iman dan mengalamkan alam.

Pendiri Yayasan SPMAA yaitu Bapak Guru Muhammad Abdullah Muchtar (Alm) memiliki pendapat tersendiri tentang lingkungan yang menjadi faktor latar belakang tujuan awal pendirian yayasan SPMAA. Berikut pendangan lingkungan menurut Bapak Guru MA Muchtar (Alm) yang dikutip oleh Gus Hafidh SKPM pada saat Deklarasi EPW (Environment Parliament Watch) di SPMAA Lamongan:

"Lingkungan adalah kesatuan antara manusia beserta segenap lingkup alam dan aspek sosialnya yang sangat berhubungan erat dalam upaya penyembahan kepada Allah SWT. Jika hubungan manusia dan Allah itu harmonis, maka lingkungan akan tertata baik. Sebaliknya, bila hubungan kepada Allah ternoda, maka tata lingkungan alam dan sosial akan rusak binasa".

Melihat nilai dasar gerakan pesantren SPMAA, maka dapat dilihat bahwa internalisasi nilai ecopesantren dalam membentuk karakter peduli lingkungan merupakan salah satu prioritas utama dalam pengembangan pendidikan pada pesantren ini. Nilai-nilai yang mendasari gerakan peduli lingkungan pada pesantren yang terdapat dalam Tiga Proyek Besar Umat Manusia dapat dijabarkan sebagai berikut:

A. Mengenal Allah Secara Mendekat \& Mendasar

1. Hidup ramah alam 
HAYULA: Indonesian Journal of Multidisciplinary Islamic Studies, Vol. 4, No. 1, Januari 2020 DOI:https://doi.org/10.21009/hayula.004.1.05

2. Transparansi dan akuntabilitas

3. Tahu dosa lingkungan

4. Menjalani tupoksi sebagai khalifah bumi yang wara

B. Melatih Diri Mengetahui Musuh Ghaib Setan

1. Hidup tidak boros

2. Anti ego sektoral

3. Hindari perilaku pezaliman lingkungan

4. Tiada kompetitor manusia. Adanya saling sinergi/penguatan aksi

C. Menanam Keyakinan Dunia Akhirat

1. Hidup sederhana

2. Layanan berpihak kepentingan umat

3. Visi masa depan pembangunan berkelanjutan

4. Akuntabel dunia akhirat

Pesantren SPMAA memiliki pandangan bahwa jika agama dan sifat manusia kembali pada aslinya, maka lingkungan beserta segenap aspek flora/fauna/sosialnya akan kembali ikut normal sesuai fungsi \& tumbuh kembangnya.

Adanya kebijakan dan pandangan pimpinan pesantren mengenai pentingnya pendidikan lingkungan atau menyisipkan materi lingkungan dalam setiap kesgiatan dan pembelajaran menjadi salah satu pendukung implementasi pendidikan lingkungan di pesantren SPMAA.

Internalisasi nilai ecopesantren dalam membentuk karakter peduli lingkungan terintegrasi dalam kebijakan visi, misi dan strategi pondok pesantren, sehingga proses internalisasi nilai dapat dilaksanakan dengan sistematis dan berkelanjutan.

\section{Internalisasi Nilai Ecopesantren dalam Membentuk Karakter Peduli Lingkungan Melalui Kurikulum Di Sekolah.}

Internalisasi nilai ecopesantren dalam membentuk karakter peduli lingkungan dilakukan melalui pengembangan kurikulum lingkungan yang berbasis Islam dimulai dengan melakukan pengembangan model pembelajaran yang terintegrasi. Kegiatan pembelajaran menerapkan model lintas mata pelajaran tematik lingkungan hidup, adanya integrasi tema lingkungan hidup dan pengembangan materi pendidikan lingkungan secara khusus. Kurikulum kemudian dikembangkan dan dirancang sebagai integrated curriculum (kurikulum terintegrasi) dengan mengacu pada perspektif yang benar mengenai tujuan 
pendidikan. Disisi lain pihak pesantren harus melengkapi kurikulum yang ada dengan kurikulum pesantren modern untuk memperkaya kurikulum nasional. Terakhir kurikulum yang sudah ada bisa diintegrasikan dengan pendidikan lingkungan hidup Kurikulum yang terdapat di Pesantren SPMAA merupakan rancangan otonomi penuh dari rancangan pesantren. Persentase kurikulum di pesantren ini adalah $70 \%$ dari pendidikan pesantren dan $30 \%$ dari pendidikan formal.

Sistem pendidikan SPMAA dikembangkan berbasiskan pesantren dan tarbiyatul ummat dengan tiga orientasi besar. Tiga orientasi besar pesantren SPMAA yakni bidang sosial, pendidikan dan lingkungan yang kemudian diberikan singkatan SOSDIKLINK (Sosial, Pendidikan dan Lingkungan) Gerbang masuk pesantren SPMAA bertuliskan "Welcome to Madrasah Open Source" memiliki makna bahwa pesantren SPMAA merupakan satuan sistem lembaga pendidikan yang menyelenggarakan pendidikan dengan sumber pembelajaran dapat berasal darimana pun, terutama sumber dari kehidupan masyarakat. Hal tersebut merupakan salah satu cerminan sistem pendidikan pesantren SPMAA yang berlandaskan tarbiyatul ummat. Selain itu, lingkungan merupakan salah satu fokus dari tiga fokus TPB (Tiga Proyek Besar). Sehingga isu lingkungan yang menjadi masalah masyarakat berkedudukan kuat dalam menjadi salah satu sumber pembelajaran di pesantren ini.

Berangkat dari isu lingkungan kemudian pesantren mengembangkan ke dalam kurikulum pesantren. Kurikulum pesantren SPMAA yang berwawasan lingkungan dapat dilihat dari adanya porsi besar perhatian yang diberikan oleh pesantren terhadap lingkungan dalam pelaksanaan pendidikannya. Seperti dalam komponen kurikulum pesantren diantaranya tujuan, materi, strategi, organisasi kurikulum dan evaluasi yang berwawasan lingkungan.

Kurikulum pesantren SPMAA yang berwawasan lingkungan dapat juga dilihat dari pelaksanaanya yang diantaranya terdapat adanya integrasi semua mata pelajaran terhadap isu-isu lingkungan, pembelajaran lingkungan melalui praktek atau pengalamaan riil mengabdi ke masyarakat, serta ditambah dengan kegiatan pesantren berbasis atau berorientasi lingkungan.

Konsep pendidikan lingkungan yang dikembangkan dalam melakukan internalisasi ecopesantren dalam membentuk karakter peduli lingkungan oleh pesantren SPMAA tersebut tetap merupakan hal yang sah untuk dikatakan sebagai pengembangan kurikulum berbasis lingkungan. Pengembangan kurikulum berbasis lingkungan pada ecopesantren pada 
HAYULA: Indonesian Journal of Multidisciplinary Islamic Studies, Vol. 4, No. 1, Januari 2020 DOI:https://doi.org/10.21009/hayula.004.1.05

hakikatnya dapat berupa; pengembangan model pembelajaran yang terintegrasi, penggalian dan pengembangan materi lingkungan hidup yang ada di masyarakat, pengembangan metode belajar berbasis lingkungan Islami, pengembangan kegiatan kurikuler untukl penoingkatan pengetahuan dan kesadaran santri tentang lingkungan hidup, pengamalan ajaran Islam tentang lingkungan hidup dalam kegiatan ecopesantren.

Pesantren telah merancang dan menerapkan kurikulum aktual berbasis ecopesantren, maka pesantren cenderung menjadikan fiqhul bi'ah sebagai mata pelajaran tersendiri yang memiliki rencana pembelajaran dan evaluasi yang baik. Sedangkan pesantren yang menerapkan hidden kurikulum berbasis ecopesantren maka akan cenderung menyisipkan materi fiqhul bi'ah kedalam materi mata pelajaran lainnya.

\section{Internalisasi Nilai Ecopesantren dalam Membentuk Karakter Peduli Lingkungan Melalui Kegiatan Ekstrakulikuler}

Kegiatan ekstrakulikuler yang dilakukan dalam membentuk karakter peduli lingkungan, melalui program ecopesantren, melaui kegiatan Pendidikan Lingkungan di luar kelas melalui Pendidikan Lingkungan Berbasis Pengalaman dan Kegiatan Lingkungan.

Kegiatan pesantren yang menjadi budaya organisasi lingkungan adalah setiap kegiatan berbasis lingkungan terutama pada orientasi kegiatan lingkungan pada tiga orientasi besar gerakan SOSDIKLINK (Sosial, Pendidikan dan Lingkungan) pada Pesantren SPMAA. Pendidikan lingkungan di pesantren dalam bentuk kegiatan lingkungan SODIKLINK lebih cenderung mengarah pada aspek kampanye lingkungan melalui PILIH (Pendidikan dan Informasi Lingkungan Hidup). PILIH merupakan gerakan lingkungan dari pesantren dengan memberikan pendidikan dan informasi lingkungan hidup terhadap masyarakat. Santri didorong aktif untuk ikut serta tidak hanya dalam kegiatan PILIH juga melalui kegiatan pelestarian lingkungan lainnya di pesantren. Dengan demikian santri juga mendapatkan pendidikan lingkungan dengan berbasis pengalaman. Internalisasi nilai ecopesantren dalam membentuk karakter peduli lingkungan terbentuk melalui kegiatan terstruktur, sehingga karakter peduli lingkungan terinternalisasi dengan baik dalam diri santri dan civitas pondok pesantren.

\section{B. Proses Internalisasi Nilai Ecopesantren Dalam Membentuk Karakter Peduli Lingkungan Di Pondok Pesantren SPMAA Lamongan Jawa Timur}

Proses internalisasi Dalam proes internalisasi yang dikaitkan dengan pembinaan peserta didik atau anak asuh ada tiga tahap yang mewakili proses atau tahap terjadinya internalisi, yaitu melalui: 
Pertama, Tahap Transformasi Nilai: Tahap ini merupakan suatu proses yang dilakukan oleh pendidik dalam menginformasikan nilai-nilai yang baik dan kurang baik. Pada tahap ini hanya terjadi komunikasi verbal antara pendidik dan peserta didik atau anak asuh. Pondok pesantren SPMAA Lamongan Jawa Timur, dalam Tahap ini, tergambar dengan jelas melalui kebijakan yang dibuat pondok pesantren, tidak terlepas dari visi dan misi pemimpin akan pentingnya karakter peduli lingkungan, visi dan misi pemimpin kemudian disosialisasikan dengan baik dan terprogram kepada pendidik atau pengurus pondok pesantren, visi dan misi terencana dengan baik melalui program-program ecopesantren, sehingga membentuk karakter peduli lingkungan.

Kedua, Tahap Transaksi Nilai : Suatu tahap pendidikan nilai dengan jalan melakukan komunikasi dua arah, atau interaksi antara peserta didik dengan pendidik yang bersifat interaksi timbal-balik. Pada tahap transaksi nilai ini, pondok pesantren melalui kebijakan pimpinan yang tertulis dalam visi dan misi serta terimplementasi dalam program kegiaatan pesantren peduli lingkungan, disosialisasikan dan terinternalisasi dengan baik, dapat dilihat dari aktifitas interaksi antara pemimpin, pendidik serta santri dan wali santri juga masyarakat, sehingga terjadi interaksi timbal balik diantara mereka.

Ketiga, Tahap Transinternalisasi : Tahap ini jauh lebih mendalam dari tahap transaksi. Pada tahap ini bukan hanya dilakukan dengan komunikasi verbal tapi juga sikap mental dan kepribadian. Jadi pada tahap ini komunikasi kepribadian yang berperan secara aktif. Tahap transinternalisasi ini dilakukan pondok pesantren SPMAA Lamongan Jawa Timur, melalui keteladanan baik dari kepala sekolah, pendidik, dan teman-teman peserta didik menirukan (imitating) dan melakukan (doing) berbagai perilaku beretika lingkungan yang sering dilihat, didengar, dan dirasakannya. pemimpin, pendidik sebagai role model dalam membentuk karakter peduli lingkungan kepada peserta didik di pondok pesantren SPMAA Lamongan.upaya yang dilakukan sekolah untuk mensosialisasikan nilai ecopesantren dalam membentuk karakter peduli lingkungan, secara terus menerus dengan memanfaatkan berbagai media yang ada, agar informasi tersebut dapat diterima (receiving) peserta didik.

Sosialisasi dilakukan baik melalui pembelajaran di kelas dan luar kelas, kegiatan ekstrakurikuler, keteladanan, pidato yang disampaikan saat upacara kesadaran nasional, sampai berbagai tulisan serta gambar yang sengaja dipajang di berbagai lokasi strategis, seperti: di dalam kelas, di taman, di dinding sekolah, pada tempat sampah, dekat pot tanaman. Kesinambungan dan konsistensi dalam melaksanakan: penegakkan aturan, pembiasaan terbimbing, serta pembinaan ahlak terpuji para peserta didik dikondisikan untuk 
HAYULA: Indonesian Journal of Multidisciplinary Islamic Studies, Vol. 4, No. 1, Januari 2020 DOI:https://doi.org/10.21009/hayula.004.1.05

mengulangi (repeating) dan membiasakan (habituating) berbagai perilaku yang baik terhadap lingkungan. Melalui: penataan suasana baik fisik maupun non fisik, pembelajaran di luar kelas, serta pendidikan realistik peserta didik dapat merasakan (feeling) secara langsung suasana atau kondisi yang dapat dindra oleh panca indra, dan diingat sebagai pengalaman menyenangkan berbagai efek positif akibat perilaku beretika lingkungan seperti: keberadaan tanaman yang memunculkan suasana teduh, sejuk, dan segar. Begitu pula sebaliknya rasa tidak nyaman yang dirasakan akibat LH yang rusak atau terganggu. Pengalaman tersebut diharapkan akan secara alamiah memunculkan rasa senang (loving) terhadap hal-hal menyenangkan yang telah dialami, sebagai dampak dari ekosistem stabil yang terpelihara fungsinya.

Pembimbingan kakak kelas di pondok pesantren melalui pengalaman langsung berinteraksi dengan LH dalam pendidikan realistik dan pembelajaran di luar kelas dapat memberikan pemahaman (understanding) terhadap materi pembelajaran yang diterimanya di dalam kelas, dan dijustifikasi melalui sosialisasi informasi yang dilakukan sekolah secara terus menerus melalui berbagai media. Seperti telah diuraikan sebelumnya, pada peserta didik kelas lima dan enam ditemukan berbagai perilaku yang berasal dari diri sendiri sebagai inisiatif berdasarkan pemahaman yang dimilikinya. Kegiatan yang dilaksanakan secara menyenangkan dan berlangsung di alam terbuka seperti kegiatan antar sekolah dalam rangka peringatan hari besar yang juga seringkali melibatkan pihak terkait, memungkinkan peserta didik melakukan, merasakan, dan mengalami perilaku beretika lingkungan sehingga dapat dianggap sebagai proses penguatan terhadap nilai-nilai etika lingkungan yang telah dikembangkan dalam diri mereka, dan akan memunculkan inisiatif (initiating).

\section{Simpulan}

Internalisasi nilai ecopesantren dalam membentuk karakter peduli lingkungan melalui; (1) Kebijakan pondok Pesantren; (2) kurikulum di sekolah; dan (3) kegiatan ekstrakulikuler. Proses internalisasi nilai dilakukan melalui 3 tahapan, yaitu, pertama; tahap transpormasi nilai, kedua; transaksi nilai dan ketiga; tahap transinternalisai nilai. Melalui sosialisasi informasi pada setiap kegiatan, baik melalui mading, medsos, dan lain sebagainya. Mekanisme internalisasi nilai etika lingkungan di pondok Pesantren SPMAA Lamongan Jawa Timur, yaitu: menerima, meniru, melakukan, mengulangi, membiasakan, merasakan, menyukai, memahami, dan berinisiatif. 


\section{Daftar Pustaka}

Abdurrahman, M. (2006, Juli 7). Terbukanya Jendela Pesantren. Harian Kompas.

Arikunto, S. (2006). Prosedur Penelitian. Jakarta: Rineka Cipta.

Aulia, R. N., Jasin, F. M., \& Irma, A. (2019). Management Of Eco-Pesantren-Based Critical Land Disaster Mitigation (Case Study Of The Hidayatullah Islamic Boarding School In Gunung Tembak Balikpapan Kalimantan). Unnes Science Education Journal https://doi.org/10.15294/usej.v8i2.31328.

Aulia, R. N., Mardhiah, I., Gunawan, A., \& Isnaini, D. E. (2018). Contribution Of Education Culture In Pesantren In Tackling Environmental Damage In Indonesia. Proceeding International Conference on University and Intellectual Culture, 44-53.

Aulia, R. N., Mardhiah, I., Gunawan, A., Isnaini, D. E., Firdaus, M., \& Narulita, S. (2018). Pesantren-based environmental management in equatorial areas. AIP Conference Proceedings.

Aulia, R. N., Setianingsih, A., \& Narulita, S. (2019). Pesantren-based disaster mitigation strategy: case study pondok pesantren Darunnajah Cipining Bogor. IOP Conference Series: Earth and Environmental Science.

Lexy, J. M. (2001). Metodologi Penelitian Kualitatif. Bandung: PT Remaja Rosda Karya.

Mangunjaya, F. M. (2014). Ekopesantren (Bagaimana Merancang Pesantren Ramah Lingkungan?) . Jakarta: Yayasan Obor Indonesia.

Munawaroh, Ghozali, I., \& Fuad. (2019). The Sustainability Strategy In The Company's Life Cycle. International Journal of Scientific \& Technology Research.

Sauri, S. (2012). Pendidikan Karakter dalam Perspektif Islam. Bandung: Rizqi.

Sauri, S. (2015, Juli 3). Peran Nilai Pesantren dalam Pendidikan Karakter. Diambil kembali dari http://berita.upi.edu

Sauri, S. (2017). Nilai Kearifan Lokal Pesantren dalam Upaya Pembinaan Karakter Santri. Nizham Journal of Islamic Studies, 21-50.

Wajdi, F., \& Aulia, R. N. (2019). Ma'had 'Aly and the Challenge of Modernizing Islamic Education in Indonesia. Hayula: Indonesian Journal of Multidisciplinary Islamic Studies DOI:https://doi.org/10.21009/hayula.003.2.04, 173. 
HAYULA: Indonesian Journal of Multidisciplinary Islamic Studies, Vol. 4, No. 1, Januari 2020 DOI:https://doi.org/10.21009/hayula.004.1.05 